\title{
Plasticity in perception: insights from color vision deficiencies
}

\author{
Zoey J. Isherwood ${ }^{1 \#}$ Daniel S. Joyce ${ }^{1 \#}$ Mohana Kuppuswamy Parthasarathy ${ }^{1 \#}$ Michael A. Webster ${ }^{1 *}$ \\ ${ }^{1}$ Department of Psychology, University of Nevada, Reno, NV, USA \\ \#Equally contributed
}

\begin{abstract}
Inherited color vision deficiencies typically result from a loss or alteration of the visual photopigments absorbing light and thus impact the very first step of seeing. There is growing interest in how subsequent steps in the visual pathway might be calibrated to compensate for the altered receptor signals, with the possibility that color coding and color percepts might be less severely impacted than the receptor differences predict. These compensatory adjustments provide important insights into general questions about sensory plasticity and the sensory and cognitive processes underlying how we experience color.
\end{abstract}

\section{Keywords}

Neural plasticity, adaptation, vision, color vision, color deficiencies

\section{Peer Review}

The peer reviewers who approve this article are:

1. Kenneth Knoblauch, Univ Lyon, Université, Claude Bernard Lyon 1, Inserm, Stem Cell and Brain Research Institute, Bron, France

Competing interests: No competing interests were disclosed.

2. Anya Hurlbert, Neuroscience, Institute of Biosciences, Newcastle University, Newcastle upon Tyne, UK Competing interests: No competing interests were disclosed.

*Corresponding author: Michael A. Webster (mwebster@unr.edu)

Competing interests: The authors declare that they have no competing interests.

Grant information: This work was supported by National Institutes of Health (NIH) grant EY-010834.

The funders had no role in study design, data collection and analysis, decision to publish, or preparation of the manuscript.

Copyright: (C) 2020 Webster MA et al. This is an open access article distributed under the terms of the Creative Commons Attribution License, which permits unrestricted use, distribution, and reproduction in any medium, provided the original work is properly cited.

How to cite this article: Isherwood ZJ, Joyce DS, Parthasarathy MK and Webster MA. Plasticity in perception: insights from color vision deficiencies. Faculty Reviews 2020 9:(8) https://doi.org/10.12703/b/9-8

Published: 13 Nov 2020, Faculty Reviews 9:(8) https://doi.org/10.12703/b/9-8 


\section{Introduction}

Plasticity is a hallmark of sensory processing. Environments vary widely over space and time, and sensory systems must continuously recalibrate to optimize coding for the current context $^{1,2}$. Importantly, the sensory apparatus also varies widely among individuals, and even within an individual there are dramatic changes over time (e.g. development and aging) and space (e.g. between central and peripheral vision). Plasticity must therefore correct for the properties not only of the world but also of the observer. These adjustments can arise at many structural levels, from large-scale cortical reorganization (e.g. when cortical areas normally devoted to one sense are recruited by other modalities when that sense is lost) ${ }^{3}$ to local synaptic dynamics ${ }^{4}$ and sensitivity regulation within cells ${ }^{5-7}$ and networks ${ }^{8,9}$. They can also occur over many timescales ${ }^{10}$, from rapid response changes within milliseconds ${ }^{11}$ to experience-dependent development ${ }^{12,13}$. Finally, they occur throughout the processing hierarchy, from adjusting receptor sensitivity to tuning cognition and learning. A major unresolved issue in neuroscience is defining the actual number of distinct mechanisms underlying neural plasticity, how they are manifest, and how they interact.

Here we discuss general issues and insights about plasticity within the specific context of common inherited color vision deficiencies. Recent studies have highlighted the potential for compensating for a color vision deficiency so that the world is described as richer in color than the sensory losses would predict. However, the nature of these compensations and whether they reflect perceptual or conceptual adjustments ${ }^{14}$ remain poorly understood. For example, a perceptual adaptation could reflect changes in the sensory signals encoding color, while a conceptual adjustment might be learning to label the percept with the same color name that others use ${ }^{15-18}$. Exploring plasticity through the lens of color vision provides a rich and unique opportunity for revealing how and how far neural coding and perceptual experience can be calibrated to discount natural physiological variations within and between observers and one that can also provide new insights into longstanding questions and controversies about the processes mediating human color vision.

\section{Human color vision}

Most animal species have the capacity for color vison, and in all known cases it is based on detecting light with two or more photoreceptor classes that differ in the wavelength sensitivity of their photopigments ${ }^{19-22}$. However, having more types of receptors does not necessarily confer a higher dimensionality of color vision ${ }^{23}$. Most humans have three classes of cone receptors maximally sensitive to short (S), medium (M), or long (L) wavelengths, and thus normal (or, more aptly, routine) color vision is trichromatic. Encoding color further depends on the neural machinery for comparing the relative cone responses, for example to determine whether the $\mathrm{L}$ cones or $\mathrm{M}$ cones are more excited by a light spectrum. These comparisons begin in the retina, in post-receptoral neurons that receive inputs of the same or opposite sign from different receptor types, and are carried within three "cardinal" mechanisms ${ }^{24}$ with distinct cell types and pathways, named for their projections to different layers of the lateral geniculate nucleus ${ }^{25-28}$. Cells in the magnocellular (M) pathway sum the $\mathrm{L}$ and $\mathrm{M}$ cones' signals and are the substrate of our luminance sensitivity $(\mathrm{L}+\mathrm{M})^{29}$. Chromatic information is instead carried by two cone-opponent cell types that receive opposing signals from the $\mathrm{L}$ and $\mathrm{M}$ cones (L-M, the parvocellular or $\mathrm{P}$ pathway) or from $\mathrm{S}$ cones opposed by both L and M (S-LM, the koniocellular or K pathway). Figure 1 illustrates the colors as defined by these two chromatic dimensions. However, these mechanisms describe only the initial steps of color coding. There are major further transformations of the cone-opponent signals in the cortex, and different transformations may arise at several different cortical stages ${ }^{30-32}$. Moreover, even within the retina, there is a possibility that color percepts are carried within pathways that combine the cones in different ways than the cardinal mechanisms ${ }^{33,34}$.

\section{Inherited color vision deficiencies}

Inherited color vision deficiencies primarily reflect alterations in the genes coding the cone photopigment opsins. The genes coding the $\mathrm{L}$ and $\mathrm{M}$ opsins lie in tandem on the $\mathrm{X}$ chromosome ${ }^{35}$. Errors in the $\mathrm{L}$ or $\mathrm{M}$ genes can lead to a loss of one receptor class (dichromacy) or to shifts in the spectral sensitivity (anomalous trichromacy) (Figure 1). The latter reduces the spectral separation between the $\mathrm{L}$ and $\mathrm{M}$ cones and thus reduces the difference signals (L-M) conveying chromatic information, resulting in reduced discrimination for this chromatic dimension. As an X-linked recessive trait, color vision deficiencies of this type are the most common and affect about $6 \%$ of males but are rare in females. Instead, female carriers for color vision deficiencies (with a normal gene on one $\mathrm{X}$ chromosome and modified gene on the other) might express both to develop a fourth dimension for color $^{36}$. However, whether and when this leads to functional tetrachromacy has been challenging to resolve ${ }^{37}$.

Simulations of color vision deficiencies are common and work by filtering the image to remove or alter the chromatic information that should be lost or weakened by their altered sensors (Figure 1). These illustrations are often closer to depicting what a trichromat would experience if they suddenly lost one class of receptors but have also incorporated comparisons from rare individuals with a color loss in only one eye to better simulate a dichromat's experience ${ }^{38}$. However, few simulations have tried to capture the impact of compensation for the receptor losses ${ }^{39}$.

Characterizing compensatory processes for inherited color vision deficiencies provides an ideal natural experiment for exploring the types and limits of plasticity in neural processing and perception. First, the deficit arises from only a single discrete change in the visual system that is restricted to the first step of vision, when the light is captured by the receptor ${ }^{35}$. This allows characterizing how the rest of the system can reorganize given a simple and highly stable change in its inputs. Second, each individual has had a lifetime experiencing the world 
A Color Normal
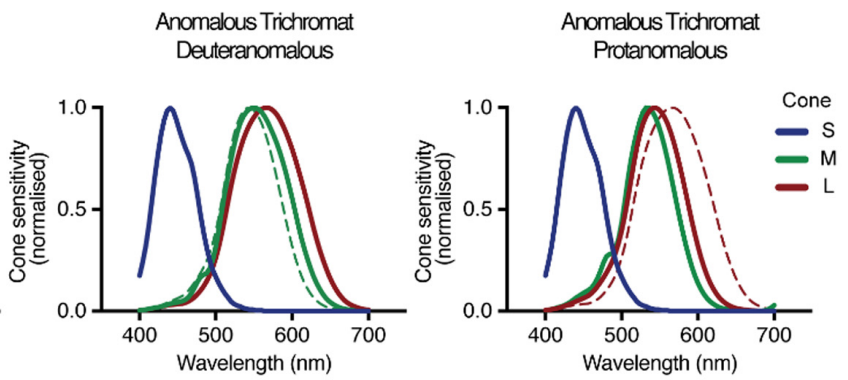

B

C

L vs $M$ and S vs LM

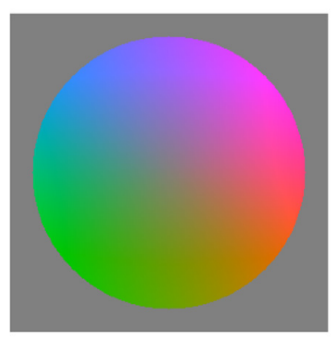

S vs LM

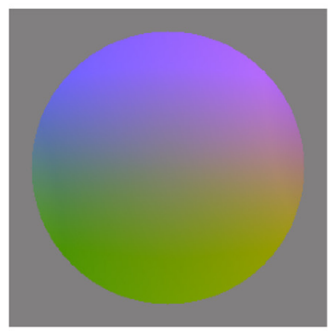

Sensitivity loss and compensation

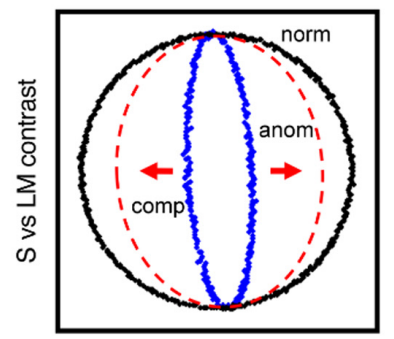

L vs M contrast
Original

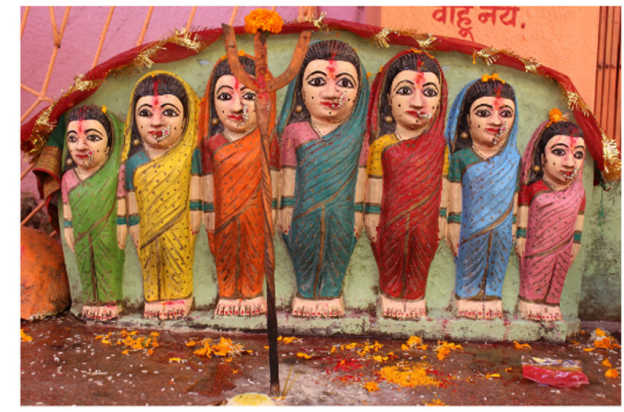

L vs M contrast removed

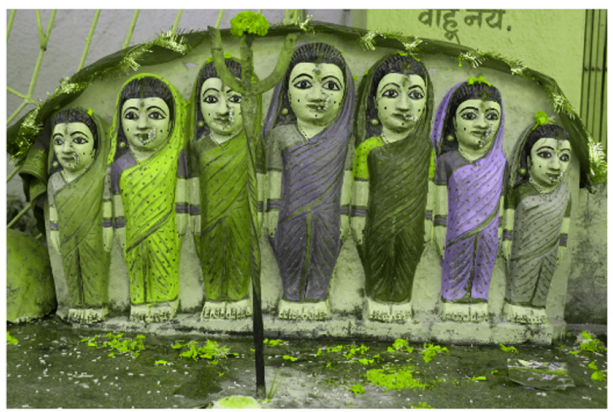

Simulated dichromat percept

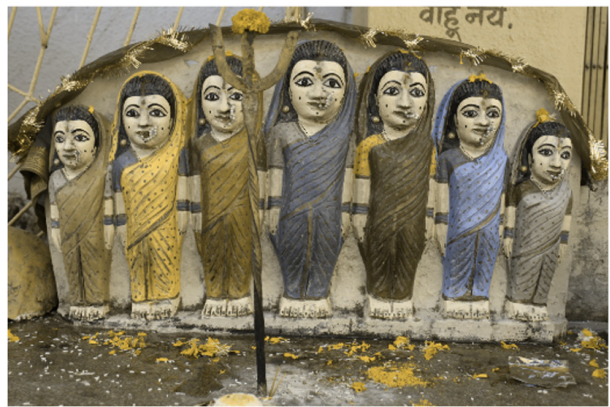

Figure 1. Simulations of color vision deficiencies. A. Routine trichromatic color vision is based on three classes of receptors with different but overlapping sensitivities. Most inherited deficiencies affect the $\mathrm{L}$ (protan) or $\mathrm{M}$ (deutan) cones, leading to their loss (dichromacy) or a shifted peak toward the unaffected cone (anomalous trichromacy). B. A space defined by the color differences signaled by comparing $L$ vs. $\mathrm{M}$ cones or the S vs. LM. Reducing the L-M signal collapses the color space toward the S vs. LM axis but could be compensated by a postreceptoral amplification. C. Filtering an image to remove the L-M contrasts removes the distinctions between reddish and greenish colors. Reports from unilateral dichromats suggest they may experience the residual colors as blue-yellow variations ${ }^{38}$. 
through their receptor complement. Thus, their perceptual capacities can reveal adaptations over timescales that are orders of magnitude longer than are typically studied in a lab, potentially revealing different mechanisms as well as the ultimate limits of sensory plasticity. Third, the spectral sensitivity differences between observers can be very precisely quantified, allowing precise predictions about their color perception and sensitive tests for any adaptive changes. Finally, a wide variety of techniques have been developed to probe color vision and to try to isolate different stages of processing, from the photopigments and early sensory coding to cognition and consciousness. Thus, different measurements can be deployed to target different levels or properties of the system in order to assess at what stages or in what tasks a compensation for the color vision deficiency occurs and what this implies about the underlying mechanisms.

\section{Compensation for color vision deficiencies}

Because dichromats completely lose one cone class, in principle there is no signal that the visual system could restore. Yet dichromats can reliably use a wide range of color terms that map onto color naming patterns for trichromats, and these abilities have been attributed to both sensory processing and learning how colors are communicated ${ }^{14,40-42}$. Dichromats also can become trichromatic for large fields by taking advantage of the changes in spectral sensitivity across the retina or information provided by rod receptors ${ }^{43}$. The rods are a fourth receptor class specialized for sensing under dim light levels. The rod system is typically described as "color blind", yet there are many examples of rod contributions to color vision $^{44}$ and color can be experienced even at low light levels at which only rods are active, perhaps because of learned associations with cone-mediated percepts ${ }^{45}$. Another intriguing possibility is the recruitment of signals arising from the intrinsically photosensitive retinal ganglion cells (ipRGCs). These recently discovered cells are in the output neural layer of the eye but directly absorb light using melanopsin as the photopigment ${ }^{46,47}$. The ipRGC pathway may primarily serve nonimage forming, or non-perceptual, visual function, including regulating circadian rhythms, sleep, mood, and cognition ${ }^{48}$. However, ipRGCs also receive inputs from cones and rods and project to visual pathways ${ }^{49,50}$. Their contributions to color perception remain difficult to isolate, but excitation of this pathway has been found to influence both brightness and color percepts ${ }^{51-55}$. To our knowledge, the possible role of these signals in color vision deficiencies remains unexplored. However, dichromats may offer a more powerful test case for probing color coding and ipRGCs because these observers may be more dependent on their signals and also because the signals themselves may be easier to isolate from the cone responses.

Recently, several theoretical and empirical studies have also explored compensation for anomalous trichromacy ${ }^{56}$. In this case, the smaller differences in the $\mathrm{L}$ and $\mathrm{M}$ cone sensitivities could in principle be discounted simply by amplifying the gain in the post-receptoral neurons that compare these signals ${ }^{39,57}$. As noted, this comparison is initially carried out in cone-opponent cells that receive opposite inputs from the $\mathrm{L}$ and $\mathrm{M}$ cones and is carried through the parvocellular pathway ${ }^{25,26}$. The rationale for amplifying their responses when the inputs are weaker is grounded in information theory, which predicts that each cell should center and scale its limited operating range for the distribution of inputs in order to maximize the information it can transmit ${ }^{58-61}$. Rescaling responses to the magnitude of luminance or chromatic variation (or contrast) is a well-established form of visual adaptation documented in countless behavioral and physiological studies ${ }^{6,762,63}$. Typically, these involve stimulating the system with high contrast and measuring the resulting sensitivity losses. Yet a small number of studies have also shown that when observers are exposed to weaker-than-normal luminance contrasts, the responses instead increase ${ }^{64-66}$, suggesting that perceived saturation should also increase in an observer habitually exposed to low L-M contrasts.

There are a number of unsolved puzzles about the impact of such post-receptoral gain adjustments. For example, adaptation could amplify not only the signal but also the noise, and thus the consequences for perception depend on where in the system sensitivity regulation and the limiting noise occur ${ }^{39,58,67}$. In addition, while color contrast adaptation is readily observed in the visual cortex, color-opponent cells at the level of the retina and LGN show substantially less adaptation ${ }^{68,69}$ (but see 70). This raises the possibility that the system could restore optimal coding in the cortex even though the chromatic signals in the retina and LGN remain weak and thus poorly calibrated to the natural environment. One potential rationale for this is that $\mathrm{P}$ cells encode both color and lightness information (because the weights of the $\mathrm{L}$ and $\mathrm{M}$ cone inputs vary substantially ${ }^{25}$ and because the cone inputs are segregated into different spatial subregions of the cell's receptive field ${ }^{71}$ ). This means that gain changes at this level not only would amplify the weakened chromatic signal but also could "over-amplify" the better preserved lightness signals. In the cortex, lightness and chromatic information may become decoupled ${ }^{72,73}$, and it may therefore be more advantageous to adapt at this stage in order to separately calibrate these signals. A still further possibility is that the retina and LGN can adjust in different ways or over longer timescales than are revealed by short-term adaptation experiments. Adaptation to color can occur over many timescales ${ }^{74-77}$. However, it remains uncertain whether adjustments with different time constants reflect similar processes and consequences but tracking different rates of change or if they reflect fundamentally different mechanisms that calibrate different aspects of the system.

Empirically, the primary evidence for compensation has come from studies comparing the perceptual reports of anomalous trichromats. For example, in a perceptual grouping task, some anomalous observers perceived L-M color differences as more salient than expected ${ }^{78}$. Similarly, estimates of the color responses from multidimensional scaling ${ }^{79,80}$ or contrast scaling $^{81}$ have found that the L-M percepts are stronger than predicted from the observer's detection thresholds and can come close to the responses for routine trichromatic observers. 
However, here again there are many unresolved questions. First, these studies rely on observers' subjective reports, and thus it is difficult to infer from these reports what they actually "see." For example, individuals could learn to interpret or label the same stimuli with the same scale or terms that others use even if they perceive them very differently, and they might base their reports on very different stimulus cues ${ }^{14,41,82}$. As noted, even dichromats can exhibit nearly normal patterns of basic color naming but might rely on different cues for this, such as luminance variations or rod signals. As such, some putative measures of color appearance and compensation may reflect more cognitive stages (such as how the sensory signals are interpreted or categorized) rather than the strength of the sensory signals themselves. Objective measures of the chromatic contrast responses in anomalous trichromacy remain lacking. However, recent studies have begun to probe compensation for color vision deficiencies with neuroimaging. For example, an fMRI study ${ }^{83}$ found that the BOLD response to L-M contrast was amplified within but not before early visual cortical areas, implicating V1 or V2 as the earliest site of the gain compensation. Another study using visual evoked potentials (VEPs) also found amplified signals, but only when the stimuli were viewed binocularly, again implicating a cortical locus for the response gains ${ }^{84}$. For monocular viewing, VEP amplitudes are substantially reduced and diagnostic of the deficiency $^{85}$.

A second question is under what conditions the compensation is manifest. Clearly, the sensitivity losses are not completely discounted because anomalous trichromats fail color screening tests, which measure the ability to discriminate small color differences. Similarly, the simple loss hypothesis closely predicts their color matching behavior (i.e. when two lights with different physical spectra will look the same), and the color matches of dichromats have played a central role in deriving the cone spectral sensitivities ${ }^{86}$. The presumed amplification instead occurs above the detection threshold, when the system "knows" a signal is there. A related example is the phenomenon of contrast constancy. Thresholds for detecting spatial contrast (e.g. in spatial sinewave gratings) are lowest for medium spatial scales, forming the characteristic bandpass contrast sensitivity function. However, when the gratings are slightly above threshold, the perceived contrast is nearly independent of spatial frequency ${ }^{87,88}$. With regard to color, greater constancy or compensation may also be manifest when the task reflects cognitive factors (e.g. learning color categories) rather than early sensory signals ${ }^{14}$.

A further challenge for interpreting these studies is that anomalous trichromacy is itself a very heterogeneous condition ${ }^{56}$. Observers can vary widely in the separation of their longer wave cones, as well as which cone class is altered, and this separation does not always predict even their performance at threshold ${ }^{89,90}$. For example, some anomalous observers who are revealed by their altered color matches nevertheless have fine color discrimination. How these individual differences impact the form and extent of compensatory adjustments remains an important question to address.
Finally, it should be emphasized that even in measures of color appearance or salience, the degree of compensation is rarely complete. That is, suprathreshold percepts may be amplified relative to threshold sensitivity but, in most anomalous observers, still fall short of the L-M responses of routine trichromats ${ }^{78,79,81,91}$. Understanding why compensation is incomplete is as important as understanding why it occurs at all. In the case of color, there may again be many factors limiting plasticity, from the problems of amplifying noise to the possibility that anomalous observers are basing their judgments on different cues (e.g. lightness variations) that may be inherently weaker. Another potential limit is that the $\mathrm{L}$ and $\mathrm{M}$ cones are thought to differ only in their opsins and thus do not have a unique physiological signature. The visual system must therefore learn the identity of each cone from the patterns of their responses to the spectra the observer experiences ${ }^{92,93}$. Misclassifications are more likely the smaller the differences between these responses, and this could introduce errors in postreceptoral coding that cannot be undone by simply amplifying those differences.

\section{Restoring color vision}

We have emphasized the advantage of assessing plasticity when the adjustment is to a stable and permanent property of the visual system. But what if that property suddenly changes? There is now the prospect for viral vector-mediated gene therapy to introduce the missing photopigment in the retina ${ }^{33}$. Dichromatic adult monkeys whose eyes were injected with a missing $\mathrm{L}$ pigment gene expressed the pigment over time and became trichromatic in their color discriminations ${ }^{94}$. This suggests that even in the adult, the post-receptoral machinery can exploit the added input signals, though the extent to which this involves tapping into existing pathways versus recalibration remains uncertain. Beyond the expanded capacity to detect colors, it is also unknown how the added receptor type will impact the perceptual experience of color ${ }^{95}$ and what forms of plasticity might adjust for these.

Techniques have also been developed to optically enhance reddish-greenish contrasts for color-anomalous observers by using notch filters. These cannot restore normal color vision ${ }^{96}$ but can alter the relative salience of different colors. A recent study found that after wearing these glasses for just a few days, the participants reported experiencing stronger L-M contrasts, even with the glasses removed ${ }^{97}$. This is surprising given that the observers had a lifetime to adjust to their cone sensitivities and because the changes are in the opposite direction to the effects predicted by adaptation (since adapting to stronger colors should have resulted in reduced sensitivity). However, similar effects have been found in perceptual training for other visual deficits (e.g. amblyopia) ${ }^{98-100}$, where requiring the observer to attend to the weakened visual signals allows them to process them more effectively. An implication of such results is that the visual system is capable of even greater plasticity when the stimulus or task demands it, and these effects have been widely studied in the context of perceptual learning ${ }^{101-104}$. How this learning interacts with other forms of plasticity like adaptation remains poorly understood but is being actively investigated ${ }^{105-109}$. 


\section{Implications for routine trichromatic color vision}

Importantly, the processes compensating for a color vision deficiency are also at play in calibrating the sensitivity and perception of individuals with routine trichromacy. For example, many authors have noted that because of the spectral overlap in the $\mathrm{L}$ and $\mathrm{M}$ cones (and, to a lesser extent, the $\mathrm{S}$ cones), their responses are very similar and for natural spectra are very highly correlated ${ }^{110-112}$. This means that the L-M chromatic signal is many times weaker than the L+M signal, which underlies our luminance sensitivity. Based on these cone contrasts, the world should appear to vary much more in brightness than color. However, post-receptoral sensitivity is correspondingly much higher for the chromatic cone contrasts ${ }^{57,113}$, to an extent that roughly matches the gamut of color signals we are exposed to in our environment ${ }^{114}$. From this perspective, then, the gain adjustments in the anomalous observers are simply the same adjustments that operate in every observer.

A further important point is that color vision deficiencies are just a more extreme case of the enormous variability inherent in human color vision. Individuals who are all classified as "normal" trichromats nevertheless differ widely in their spectral sensitivities because of differences in the lens and macular screening pigments, the specific absorption spectra of the cones, and the relative number of the $\mathrm{L}$ and $\mathrm{M}$ cones ${ }^{115-117}$. Spectral sensitivity differences influence an observer's color matches (i.e. which physically different spectra appear identical) but have surprisingly little impact on measurements of color appearance ${ }^{118,119}$. For example, what looks gray does not vary with age despite the yellowing lens ${ }^{120,121}$ and does not vary with space despite the drop in macular screening pigment outside the central fovea ${ }^{122,123}$, and the relative sensitivities of the different cone classes also show little change with age $\mathrm{e}^{124,125}$. Similarly, the $\mathrm{L}$ to $\mathrm{M}$ cone ratios strongly impact luminance sensitivity but have little influence on color percepts ${ }^{126-128}$. Again, this is because each individual's visual system is calibrated for their environment ${ }^{63,118}$. Thus, what looks gray is as much a property of the environment (e.g. the average spectral stimulus) as the visual system representing it ${ }^{129,130}$.

Comparing different stages of color coding in routine and color-deficient observers could continue to help resolve some of the ongoing challenges of understanding the bases for human color vision and what different measurements of color perception actually reflect. Traditional models of color vision assume that subjective color appearance depends on two chromatic opponent processes signaling red vs. green or blue vs. yellow sensations. Yet, while opponency is well established by both behavioral and physiological measures ${ }^{131}$, the red-green and blue-yellow axes of color appearance do not agree with the early precortical dimensions along which color is encoded (i.e. the L-M and S-LM mechanisms) ${ }^{24}$. This has suggested that the red-green and blue-yellow processes arise at later stages ${ }^{132}$ or are carried along different pathways ${ }^{33,34}$. However, there is also growing uncertainty around whether these canonical hue processes exist at all ${ }^{118}$. A clear neural signature for these perceptual processes has yet to be identified, and the special colors they predict (e.g. pure red-green or blue-yellow) do not appear special in many behavioral tasks ${ }^{133-135}$. Thus, the visual representation of color-at stages closer to our conscious percepts-is, in reality, very poorly understood. Measurements with coloranomalous observers can be used to test which aspects of these percepts can be equated across observers with fundamentally different receptor constraints, and this may in turn elucidate the basis for this equivalence. For example, neuroimaging studies have attempted to identify different stages of color coding and the cortical sites at which the neural representation of color begins to resemble the perceptual organization of color ${ }^{136-138}$. If these representations look different for routine and anomalous observers, yet their color reports agree, then we would need to look elsewhere to understand the nature of these reports. More generally, tests of plasticity and compensation in color vision deficiencies may reveal which types of measurements uncover intrinsic signals within our senses versus the cognitive strategies involved in their readout.

\section{Conclusion}

While color vision deficiencies are often modeled as a reduced form of standard trichromatic color vision, many lines of evidence point to compensatory adjustments that can partially discount the consequences of the receptor loss or change. Understanding these adjustments - their number, nature, and limits - can shed important light on general principles of adaptation and plasticity in sensory systems and on the still poorly understood basis of human color experience.
1. Olshausen BA, Field DJ: Natural image statistics and efficient coding. Network 1996; 7(2): 333-9.

PubMed Abstract | Publisher Full Text

2. Geisler WS: Visual perception and the statistical properties of natural scenes. Annu Rev Psychol. 2008; 59: 167-92. PubMed Abstract | Publisher Full Text

3. Fine I, Park JM: Blindness and Human Brain Plasticity. Annu Rev Vis Sci. 2018 4: 337-56.

PubMed Abstract | Publisher Full Text

4. Berry KP, Nedivi E: Experience-Dependent Structural Plasticity in the Visual
System. Annu Rev Vis Sci. 2016; 2: 17-35. PubMed Abstract | Publisher Full Text | Free Full Text

5. Cameron MA, Morley JW, Pérez-Fernández V: Seeing the light: Different photoreceptor classes work together to drive adaptation in the mammalian retina. Curr Opin Physiol. 2020; 16: 43-9. Publisher Full Text

6. Clifford CWG, Webster MA, Stanley GB, et al.: Visual adaptation: Neural, psychological and computational aspects. Vision Res. 2007; 47(25): 3125-31. PubMed Abstract | Publisher Full Text

7. Kohn A: Visual adaptation: Physiology, mechanisms, and functional benefits. 
J Neurophysiol. 2007; 97(5): 3155-64

PubMed Abstract | Publisher Full Text

8. Solomon SG, Kohn A: Moving sensory adaptation beyond suppressive effects in single neurons. Curr Biol. 2014; 24(20): R1012-22. PubMed Abstract | Publisher Full Text | Free Full Text Faculty Opinions Recommendation

9. Carandini M, Heeger DJ: Normalization as a canonical neural computation Nat Rev Neurosci. 2011; 13(1): 51-62. PubMed Abstract | Publisher Full Text | Free Full Text | Faculty Opinions Recommendation

10. Kording KP, Tenenbaum JB, Shadmehr R: The dynamics of memory as a consequence of optimal adaptation to a changing body. Nat Neurosci. 2007; 10(6): 779-86.

PubMed Abstract | Publisher Full Text | Free Full Text | Faculty Opinions Recommendation

11. Glasser DM, Tsui JMG, Pack CC, et al.: Perceptual and neural consequences of rapid motion adaptation. Proc Natl Acad Sci U S A. 2011; 108(45): E1080-8. PubMed Abstract | Publisher Full Text | Free Full Text

12. Sugita Y: Experience in early infancy is indispensable for color perception. Curr Biol. 2004; 14(14): 1267-71.

PubMed Abstract | Publisher Full Text | Faculty Opinions Recommendation

13. Brown AM: Development of visual sensitivity to light and color vision in human infants: A critical review. Vision Res. 1990; 30(8): 1159-88. PubMed Abstract | Publisher Full Text

14. Shepard RN, Cooper LA: Representation of Colors in the Blind, Color-Blind, and Normally Sighted. Psychol Sci. 1992; 3(2): 97-104. Publisher Full Tex

15. Witzel C, Gegenfurtner KR: Color Perception: Objects, Constancy, and Categories. Annu Rev Vis Sci. 2018; 4: 475-99. PubMed Abstract | Publisher Full Text

16. Park J, Tauber S, Jameson KA, et al: The Evolution of Shared Concepts in Changing Populations. Rev Phil Psych. 2019; 10: 479-98. Publisher Full Text

17. Gibson E, Futrell R, Jara-Ettinger J, et al:: Color naming across languages reflects color use. Proc Natl Acad Sci U S A. 2017; 114(40): 10785-90. PubMed Abstract | Publisher Full Text | Free Full Text Faculty Opinions Recommendation

18. Lindsey DT, Brown AM, Brainard DH, et al:: Hunter-Gatherer Color Naming Provides New Insight into the Evolution of Color Terms. Curr Biol. 2015; 25(18): 2441-6.

PubMed Abstract | Publisher Full Text | Free Full Text

Faculty Opinions Recommendation

19. Jacobs GH: The evolution of vertebrate color vision. Adv Exp Med Biol. 2012 739: 156-72. PubMed Abstract | Publisher Full Text

20. Baden T, Osorio D: The Retinal Basis of Vertebrate Color Vision. Annu Rev Vis Sci. 2019; 5: 177-200.

PubMed Abstract | Publisher Full Text | Faculty Opinions Recommendation

21. Osorio D, Vorobyev M: Photoreceptor spectral sensitivities in terrestrial animals: Adaptations for luminance and colour vision. Proc Biol Sci. 2005 272(1574): 1745-52.

PubMed Abstract | Publisher Full Text | Free Full Text

22. Cuthill IC, Allen WL, Arbuckle K, et al.: The biology of color. Science. 2017; 357(6350): eaan0221.

PubMed Abstract | Publisher Full Text

23. Jacobs GH: Photopigments and the dimensionality of animal color vision Neurosci Biobehav Rev. 2018; 86: 108-30.

PubMed Abstract | Publisher Full Text | Faculty Opinions Recommendation

24. Krauskopf J, Williams DR, Heeley DW: Cardinal directions of color space. Vision Res. 1982; 22(9): 1123-31.

PubMed Abstract | Publisher Full Text

25. Derrington AM, Krauskopf $\mathrm{J}$, Lennie $\mathrm{P}$ : Chromatic mechanisms in lateral geniculate nucleus of macaque. J Physiol. 1984; 357: 241-65. PubMed Abstract | Publisher Full Text | Free Full Text

26. Dacey DM: Parallel pathways for spectral coding in primate retina. Annu Rev Neurosci. 2000; 23: 743-75.

PubMed Abstract | Publisher Full Text

27. Martin PR, White AJ, Goodchild AK, et al: Evidence that blue-on cells are part of the third geniculocortical pathway in primates. Eur J Neurosci. 1997; 9(7): 1536-41.

PubMed Abstract | Publisher Full Text

28. Lee BB: Color coding in the primate visual pathway: A historical view. J Opt Soc Am A Opt Image Sci Vis. 2014; 31(4): A103-12.

PubMed Abstract | Publisher Full Text

29. Lennie P, Pokorny J, Smith VC: Luminance. J Opt Soc Am A. 1993; 10(6): 1283-93.

PubMed Abstract | Publisher Full Text

30. Conway BR, Eskew RT, Martin PR, et al:: A tour of contemporary color vision research Vision Res. 2018; 151:2-6.

PubMed Abstract | Publisher Full Text | Free Full Text

31. Gegenfurtner KR: Cortical mechanisms of colour vision. Nat Rev Neurosci. 2003; $4(7): 563-72$

PubMed Abstract | Publisher Full Text

32. Conway BR: The Organization and Operation of Inferior Temporal Cortex. Annu Rev Vis Sci. 2018; 4: 381-402.

PubMed Abstract | Publisher Full Text | Free Full Text

33. Neitz J, Neitz M: Evolution of the circuitry for conscious color vision in primates. Eye (Lond). 2017; 31(2): 286-300.

PubMed Abstract | Publisher Full Text | Free Full Text

34. Patterson SS, Neitz M, Neitz J: Reconciling Color Vision Models With Midget Ganglion Cell Receptive Fields. Front Neurosci. 2019; 13: 865. PubMed Abstract | Publisher Full Text | Free Full Text | Faculty Opinions Recommendation

35. Neitz J, Neitz M: The genetics of normal and defective color vision. Vision Res. 2011; 51(7): 633-51.

PubMed Abstract | Publisher Full Text | Free Full Text

36. Jameson KA, Satalich TA, Joe KC, et al.: Human Color Vision and Tetrachromacy (Elements in Perception). Cambridge University Press. 2020.

Reference Source

37. Jordan G, Mollon J: Tetrachromacy: The mysterious case of extra-ordinary color vision. Curr Opin Behav Sci. 2019; 30: 130-134. Publisher Full Text | Faculty Opinions Recommendation

38. Viénot F, Brettel H, Ott L, et al.: What do colour-blind people see? Nature. 1995; 376(6536): 127-8.

PubMed Abstract | Publisher Full Tex

39. Webster MA, Juricevic I, McDermott KC: Simulations of adaptation and color appearance in observers with varying spectral sensitivity. Ophthalmic Physiol Opt. 2010; 30(5): 602-10.

PubMed Abstract | Publisher Full Text | Free Full Text

40. Wachtler T, Dohrmann U, Hertel R: Modeling color percepts of dichromats Vision Res. 2004; 44(24): 2843-55.

PubMed Abstract | Publisher Full Text

41. Bonnardel V: Color naming and categorization in inherited color vision deficiencies. Vis Neurosci. 2006; 23(3-4): 637-43. PubMed Abstract | Publisher Full Text

42. Jameson D, Hurvich LM: Dichromatic color language: "reds" and "greens" don" look alike but their colors do. Sens Processes. 1978; 2(2): 146-55. PubMed Abstract

43. Smith VC, Pokorny J: Large-field trichromacy in protanopes and deuteranopes. J Opt Soc Am. 1977; 67(2): 213-20. PubMed Abstract | Publisher Full Text

44. Buck SL: The interaction of rod and cone signals: pathways and psychophysics. In: The New Visual Neurosciences. 2014; 485-497.

45. Elliott SL, Cao D: Scotopic hue percepts in natural scenes. J Vis. 2013; 13(13): 15.

PubMed Abstract | Publisher Full Text | Free Full Text

46. Provencio I, Rollag MD, Castrucci AM: Photoreceptive net in the mammalian retina. This mesh of cells may explain how some blind mice can still tell day from night. Nature. 2002; 415(6871): 493 PubMed Abstract | Publisher Full Tex

47. Berson DM, Dunn FA, Takao M: Phototransduction by retinal ganglion cells that set the circadian clock. Science. 2002; 295(5557): 1070-3. PubMed Abstract | Publisher Full Text | Faculty Opinions Recommendation

48. Schmidt TM, Chen SK, Hattar S: Intrinsically photosensitive retinal ganglion cells: Many subtypes, diverse functions. Trends Neurosci. 2011; 34(11): 572-80. PubMed Abstract | Publisher Full Text | Free Full Text

49. Dacey DM, Liao HW, Peterson BB, et al:: Melanopsin-expressing ganglion cells in primate retina signal colour and irradiance and project to the LGN. Nature. 2005; 433(7027): 749-54.

PubMed Abstract | Publisher Full Text | Faculty Opinions Recommendation

50. Patterson SS, Kuchenbecker JA, Anderson JR, et al.: A Color Vision Circuit for Non-Image-Forming Vision in the Primate Retina. Curr Biol. 2020; 30(7): 1269-1274.e2.

PubMed Abstract | Publisher Full Text | Free Full Text |

Faculty Opinions Recommendation

51. Cao D, Chang A, Gai S: Evidence for an impact of melanopsin activation on unique white perception. J Opt Soc Am A Opt Image Sci Vis. 2018; 35(4): B287B291.

PubMed Abstract | Publisher Full Text | Free Full Text

52. Horiguchi $\mathrm{H}$, Winawer J, Dougherty RF, et al.: Human trichromacy revisited. Proc Natl Acad Sci U S A. 2013; 110(3): E260-9.

PubMed Abstract | Publisher Full Text | Free Full Tex

53. Zele AJ, Feigl B, Adhikari $\mathrm{P}$, et al:: Melanopsin photoreception contributes to human visual detection, temporal and colour processing. Sci Rep. 2018; 8(1): 3842.

PubMed Abstract | Publisher Full Text | Free Full Text

54. DeLawyer T, Tsujimura SI, Shinomori K: Relative contributions of melanopsin to 
brightness discrimination when hue and luminance also vary. J Opt Soc Am A Opt Image Sci Vis. 2020; 37(4): A81-A88.

PubMed Abstract | Publisher Full Text

55. Lucas RJ, Allen AE, Milosavljevic N, et al.: Can We See with Melanopsin? Annu Rev Vis Sci. 2020; 6: 453-468.

PubMed Abstract | Publisher Full Text

56. Bosten J: The known unknowns of anomalous trichromacy. Curr Opin Behav Sci. 2019; 30: 228-37.

Publisher Full Text | Faculty Opinions Recommendation

57. MacLeod DIA: The Verriest Lecture: Colour discrimination, colour constancy and natural scene statistics. In: Normal and Defective Colour Vision. J.D.M. Mollon, J. Pokorny, and K. Knoblauch, Editors. Oxford University Press: Oxford. 2003; 189-217.

58. von der Twer T, MacLeod DIA: Optimal nonlinear codes for the perception of natural colours. Network. 2001; 12(3): 395-407.

PubMed Abstract | Publisher Full Text

59. Laughlin SA: A simple coding procedure enhances a neuron's information capacity. Z Naturforsch C Biosci. 1981; 36(9-10): 910-2. PubMed Abstract | Publisher Full Text | Faculty Opinions Recommendation

60. Buchsbaum G, Gottschalk A: Trichromacy, opponent colours coding and optimum colour information transmission in the retina. Proc $R$ Soc Lond B Biol Sci. 1983; 220(1218): 89-113.

PubMed Abstract | Publisher Full Text

61. Atick JJ, Li Z, Redlich AN: Understanding Retinal Color Coding from First Principles. Neural Comput. 1992; 4(4): 559-72.

Publisher Full Text

62. Webster MA: Adaptation and visual coding. J Vis. 2011; 11(5): 1-23. PubMed Abstract | Publisher Full Text | Free Full Text

63. Webster MA: Visual Adaptation. Annu Rev Vis Sci. 2015; 1: 547-67. PubMed Abstract | Publisher Full Text | Free Full Text | Faculty Opinions Recommendation

64. Kwon M, Legge GE, Fang F, et al:: Adaptive changes in visual cortex following prolonged contrast reduction. J Vis. 2009; 9(2): 20.1-16. PubMed Abstract | Publisher Full Text | Free Full Text | Faculty Opinions Recommendation

65. Zhang $\mathrm{P}, \mathrm{Bao} \mathrm{M}, \mathrm{Kwon} \mathrm{M}$, et al:: Effects of orientation-specific visual deprivation induced with altered reality. Curr Biol. 2009; 19(22): 1956-60. PubMed Abstract | Publisher Full Text | Faculty Opinions Recommendation

66. Hata W, Motoyoshi I: Bidirectional aftereffects in perceived contrast. J Vis. 2018; 18(9): 12

PubMed Abstract | Publisher Full Text

67. Rieke F, Rudd ME: The challenges natural images pose for visual adaptation. Neuron. 2009; 64(5): 605-16.

PubMed Abstract | Publisher Full Text

68. Solomon SG, Peirce JW, Dhruv NT, et al:: Profound Contrast Adaptation Early in the Visual Pathway. Neuron. 2004; 42(1): 155-62. PubMed Abstract | Publisher Full Text

69. Lutze M, Pokorny J, Smith VC: Achromatic parvocellular contrast gain in normal and color defective observers: Implications for the evolution of color vision. Vis Neurosci. 2006; 23(3-4): 611-6.

PubMed Abstract | Publisher Full Text

70. Chang DHF, Hess RF, Mullen KT: Color responses and their adaptation in human superior colliculus and lateral geniculate nucleus. Neurolmage. 2016; 138: 211-20.

PubMed Abstract | Publisher Full Text

71. De Valois RL, De Valois KK: Neural coding of color. In Readings on color, The science of color, A. Byrne and D.R. Hilbert, Editors., MIT Press. 1997; 2: 93-140. Reference Source

72. Shapley R, Hawken MJ: Color in the cortex: Single- and double-opponent cells. Vision Res. 2011; 51(7): 701-17. PubMed Abstract | Publisher Full Text | Free Full Text

73. Kingdom FA, Mullen KT: Separating colour and luminance information in the visual system. Spat Vis. 1995; 9(2): 191-219. PubMed Abstract | Publisher Full Text

74. Tregillus KEM, Engel SA: Long-term adaptation to color. Curr Opin Behav Sci. 2019; 30: 116-21.

Publisher Full Text

75. Delahunt PB, Webster MA, Ma L, et al.: Long-term renormalization of chromatic mechanisms following cataract surgery. Vis Neurosci. 2004; 21(3): 301-7. PubMed Abstract | Publisher Full Text | Free Full Text

76. Neitz J, Carroll J, Yamauchi Y, et al.: Color Perception Is Mediated by a Plastic Neural Mechanism that Is Adjustable in Adults. Neuron. 2002; 35(4): 783-92. PubMed Abstract | Publisher Full Text

77. Belmore SC, Shevell SK: Very-long-term and short-term chromatic adaptation: Are their influences cumulative? Vision Res. 2011; 51(3): 362-6. PubMed Abstract | Publisher Full Text | Free Full Text

78. Regan BC, Mollon JD: The relative salience of the cardinal axes of colour space in normal and anomalous trichromats. In Colour Vision Deficiencies C.R.
Cavonius, Editor, Dordrecht: Kluwer. 1997; 261-270. Publisher Full Text

79. Boehm AE MacLeod DIA, Bosten JM: Compensation for red-green contrast loss in anomalous trichromats. J Vis. 2014; 14(13): 19 PubMed Abstract | Publisher Full Text | Free Full Text | Faculty Opinions Recommendation

80. Paramei GV: Color Space of Normally Sighted and Color-Deficient Observers Reconstructed from Color Naming. Psychol Sci. 1996; 7(5): 311-7. Publisher Full Text

81. Knoblauch K, Marsh-Armstrong B, Werner JS: Suprathreshold contrast response in normal and anomalous trichromats. J Opt Soc Am A Opt Image Sci Vis. 2020; 37(4): A133-A144.

PubMed Abstract | Publisher Full Text | Faculty Opinions Recommendation

82. Mollon JD, Jordan G: On the nature of unique hues. In John Dalton's Colour Vision Legacy, C. Dickenson, I. Maurray, and D. Carden, Editors., Taylor and Francis: London. 1997

Reference Source

83. Tregillus KE: Color perception in anomalous trichromats: Neuroimaging investigations of neural compensation for losses in spectral sensitivity. (doctoral dissertation). 2017. Reference Source

84. Rabin J, Kryder A, Lam D: Binocular facilitation of cone-specific visual evoked potentials in colour deficiency. Clin Exp Optom. 2018; 101(1): 69-72. PubMed Abstract | Publisher Full Text | Faculty Opinions Recommendation

85. Crognale MA, Switkes E, Rabin J, et al:: Application of the spatiochromatic visual evoked potential to detection of congenital and acquired color-vision deficiencies. J Opt Soc Am A Opt Image Sci Vis. 1993; 10(8): 1818-25. PubMed Abstract | Publisher Full Text

86. Stockman A: Cone fundamentals and CIE standards. Curr Opin Behav Sci. 2019; 30: 87-93.

Publisher Full Text

87. Georgeson MA, Sullivan GD: Contrast constancy: Deblurring in human vision by spatial frequency channels. J Physiol. 1975; 252(3): 627-56. PubMed Abstract | Publisher Full Text | Free Full Text

88. Brady N, Field DJ: What's constant in contrast constancy? The effects of scaling on the perceived contrast of bandpass patterns. Vision Res. 1995; 35(6): 739-56.

PubMed Abstract | Publisher Full Text

89. Shevell SK, He JC, Kainz P, et al.: Relating color discrimination to photopigment genes in deutan observers. Vision Res. 1998; 38(21): 3371-6. PubMed Abstract | Publisher Full Text

90. Barbur JL, Rodriguez-Carmona M, Harlow JA, et al:: A study of unusual Rayleigh matches in deutan deficiency. Vis Neurosci. 2008; 25(3): 507-16. PubMed Abstract | Publisher Full Text | Free Full Text

91. Romeskie M: Chromatic opponent-response functions of anomalous trichromats. Vision Res. 1978; 18(11): 1521-32. PubMed Abstract | Publisher Full Text

92. Wachtler T, Doi E, Lee TW, et al:: Cone selectivity derived from the responses of the retinal cone mosaic to natural scenes. J Vis. 2007; 7(8): 6 PubMed Abstract | Publisher Full Text | Free Full Text

93. Benson NC, Manning JR, Brainard DH: Unsupervised learning of cone spectral classes from natural images. PLoS Comput Biol. 2014; 10(6): e1003652. PubMed Abstract | Publisher Full Text | Free Full Text

94. Mancuso K, Hauswirth WW, Li Q, et al:: Gene therapy for red-green colour blindness in adult primates. Nature. 2009; 461(7265): 784-7. PubMed Abstract | Publisher Full Text | Free Full Text | Faculty Opinions Recommendation

95. Cornelissen FW, Brenner E: Is adding a new class of cones to the retina sufficient to cure color-blindness? J Vis. 2015; 15(13): 22 PubMed Abstract | Publisher Full Text

96. Gómez-Robledo L, Valero EM, Huertas R, et al:: Do EnChroma glasses improve color vision for colorblind subjects? Opt Express. 2018; 26(22): 28693-703. PubMed Abstract | Publisher Full Text

97. Werner JS, Marsh-Armstrong B, Knoblauch K: Adaptive Changes in Color Vision from Long-Term Filter Usage in Anomalous but Not Normal Trichromacy. Curr Biol. 2020; 20(15): 3011-3015. Publisher Full Text | Faculty Opinions Recommendation

98. Bavelier D, Green CS, Pouget A, et al:: Brain plasticity through the life span: learning to learn and action video games. Annu Rev Neurosci. 2012; 35 391-416.

PubMed Abstract | Publisher Full Text

99. Levi DM, Li RW: Perceptual learning as a potential treatment for amblyopia: a mini-review. Vision Res. 2009; 49(21): 2535-49. PubMed Abstract | Publisher Full Text | Free Full Text

100. Lu ZL, Yu C, Watanabe T, et al.: Perceptual learning: functions, mechanisms, and applications. Vision Res. 2010; 50(4): 365-7. PubMed Abstract | Publisher Full Text | Free Full Text

101. Dosher B, Lu ZL: Visual Perceptual Learning and Models. Annu Rev Vis Sci. 
2017; 3: 343-63.

PubMed Abstract | Publisher Full Text | Free Full Text

102. Lu ZL, Lin Z, Dosher BA: Translating Perceptual Learning from the Laboratory to Applications. Trends Cogn Sci. 2016; 20(8): 561-3. PubMed Abstract | Publisher Full Text | Free Full Text

103. Watanabe T, Sasaki Y: Perceptual learning: toward a comprehensive theory. Annu Rev Psychol. 2015; 66: 197-221. PubMed Abstract | Publisher Full Text | Free Full Text

104. Li W: Perceptual Learning: Use-Dependent Cortical Plasticity. Annu Rev Vis Sci. 2016; 2: 109-30.

PubMed Abstract | Publisher Full Text

105. McGovern DP, Roach NW, Webb BS: Perceptual learning reconfigures the effects of visual adaptation. J Neurosci. 2012; 32(39): 13621-9. PubMed Abstract | Publisher Full Text | Free Full Text

106. Yehezkel O, Sagi D, Sterkin A, et al.: Learning to adapt: Dynamics of readaptation to geometrical distortions. Vision Res. 2010; 50(16): 1550-8. PubMed Abstract | Publisher Full Text | Faculty Opinions Recommendation

107. Censor N, Harris H, Sagi D: A dissociation between consolidated perceptual learning and sensory adaptation in vision. Sci Rep. 2016; 6: 38819. PubMed Abstract | Publisher Full Text | Free Full Text

108. Dong X, Bao M: Direction selective habituation of motion adaptation. J Vis. 2019; 19(4): 6. PubMed Abstract | Publisher Full Text

109. Dong X, Gao Y, Lv L, et al.: Habituation of visual adaptation. Sci Rep. 2016; 6 19152. PubMed Abstract | Publisher Full Text | Free Full Text

110. Foster $\mathrm{DH}, \mathrm{Nascimento} \mathrm{SM}$ : Relational colour constancy from invariant coneexcitation ratios. Proc Biol Sci. 1994; 257(1349): 115-21. PubMed Abstract | Publisher Full Text

111. Ruderman DL, Cronin TW, Chiao CC: Statistics of cone responses to natura images: Implications for visual coding. J Opt Soc Am A. 1998; 15(8): 2036-2045. Publisher Full Text

112. Lee TW, Wachtler T, Sejnowski TJ: Color opponency is an efficient representation of spectral properties in natural scenes. Vision Res. 2002; 42(17): 2095-103. PubMed Abstract | Publisher Full Text | Free Full Text

113. Chaparro A, Stromeyer CF 3rd, Huang EP, et al.: Colour is what the eye sees best. Nature. 1993; 361(6410): 348-50. PubMed Abstract | Publisher Full Tex

114. McDermott KC, Webster MA: The perceptual balance of color. J Opt Soc Am A Opt Image Sci Vis. 2012; 29(2): A108-17. PubMed Abstract | Publisher Full Text | Free Full Text

115. Asano Y, Fairchild MD, Blondé L: Individual Colorimetric Observer Model. PLoS One. 2016; 11(2): e0145671. PubMed Abstract | Publisher Full Text | Free Full Text

116. Webster MA, MacLeod DI: Factors underlying individual differences in the color matches of normal observers. J Opt Soc Am A. 1988; 5(10): 1722-35. PubMed Abstract | Publisher Full Text

117. Hofer $\mathrm{H}$, Carroll J, Neitz J, et al:: Organization of the human trichromatic cone mosaic. J Neurosci. 2005; 25(42): 9669-79. PubMed Abstract | Publisher Full Text | Free Full Text Faculty Opinions Recommendation

118. Webster MA: The Verriest Lecture: Adventures in blue and yellow. J Opt Soc Am A Opt Image Sci Vis. 2020; 37(4): V1-V14. PubMed Abstract | Publisher Full Text | Free Full Text

119. Emery KJ, Webster MA: Individual differences and their implications for color perception. Curr Opin Behav Sci. 2019; 30: 28-33. PubMed Abstract | Publisher Full Text | Free Full Text

120. Wuerger S: Colour constancy across the life span: evidence for compensatory mechanisms. PLoS One. 2013; 8(5): e63921. PubMed Abstract | Publisher Full Text | Free Full Text

121. Werner JS, Schefrin BE: Loci of achromatic points throughout the life span.
J Opt Soc Am A. 1993; 10(7): 1509-16. PubMed Abstract | Publisher Full Text

122. Webster MA, Leonard D: Adaptation and perceptual norms in color vision. $J$ Opt Soc Am A Opt Image Sci Vis. 2008; 25(11): 2817-25. PubMed Abstract | Publisher Full Text | Free Full Tex

123. Bompas A, Powell G, Sumner P: Systematic biases in adult color perception persist despite lifelong information sufficient to calibrate them. J Vis. 2013; 13(1): 19.

PubMed Abstract | Publisher Full Text

124. Werner JS, Steele VG: Sensitivity of human foveal color mechanisms throughout the life span. J Opt Soc Am A. 1988; 5(12): 2122-30. PubMed Abstract | Publisher Full Text

125. Knoblauch K, Vital-Durand F, Barbur JL: Variation of chromatic sensitivity across the life span. Vision Res. 2001; 41(1): 23-36. PubMed Abstract | Publisher Full Text

126. Brainard DH, Roorda A, Yamauchi $Y$, et al:: Functional consequences of the relative numbers of $\mathrm{L}$ and $\mathrm{M}$ cones. J Opt Soc Am A Opt Image Sci Vis. 2000; 17(3): 607-14.

PubMed Abstract | Publisher Full Text

127. Miyahara E, Pokorny J, Smith VC, et al:: Color vision in two observers with highly biased LWS/MWS cone ratios. Vision Res. 1998; 38(4): 601-12. PubMed Abstract | Publisher Full Tex

128. Jordan G. Mollon JD: Unique hues in heterozygotes for protan and deutan deficiencies. In: Colour Vision Deficiencies XIII, C.R. Cavonius, Editor, Kluwer: Dordrecht. 1997; 67-76. Publisher Full Text

129. Bosten JM, Beer RD, MacLeod DIA: What is white? J Vis. 2015; 15: 5 PubMed Abstract | Publisher Full Text | Free Full Text

130. Walraven J, Werner JS: The invariance of unique white; a possible implication for normalizing cone action spectra. Vision Res. 1991; 31(12): 2185-93. PubMed Abstract | Publisher Full Text

131. Shevell SK, Martin PR: Color opponency: Tutorial. J Opt Soc Am A Opt Image Sci Vis. 2017; 34(7): 1099-108. PubMed Abstract | Publisher Full Text | Free Full Text

132. de Valois RL, de Valois KK: A multi-stage color model. Vision Res. 1993; 33: 1053-65.

PubMed Abstract | Publisher Full Text

133. Emery KJ, Volbrecht VJ, Peterzell DH, et al:: Variations in normal color vision. VI. Factors underlying individual differences in hue scaling and their implications for models of color appearance. Vision Res. 2017; 141: 51-65. PubMed Abstract | Publisher Full Text | Free Full Text

134. Bosten JM, Boehm AE: Empirical evidence for unique hues? J Opt Soc Am A Op Image Sci Vis. 2014; 31(4): A385-93. PubMed Abstract | Publisher Full Text

135. Wool LE, Komban SJ, Kremkow J, et al: Salience of unique hues and implications for color theory. J Vis. 2015; 15(2): 10. PubMed Abstract | Publisher Full Text | Free Full Tex

136. Brouwer GJ, Heeger DJ: Decoding and reconstructing color from responses in human visual cortex. J Neurosci. 2009; 29(44): 13992-4003. PubMed Abstract | Publisher Full Text | Free Full Text | Faculty Opinions Recommendation

137. Kim I, Hong SW, Shevell SK, et al:: Neural representations of perceptual color experience in the human ventral visual pathway. Proc Natl Acad Sci U S A. 2020; 117(23): 13145-50. PubMed Abstract | Publisher Full Text | Free Full Text | Faculty Opinions Recommendation

138. Lafer-Sousa R, Conway BR: Parallel, multi-stage processing of colors, faces and shapes in macaque inferior temporal cortex. Nat Neurosci. 2013; 16(12): $1870-8$.

PubMed Abstract | Publisher Full Text | Free Full Text |

Faculty Opinions Recommendation 